\title{
TECHNOLOGY EXPERIMENTAL IMPLEMENTATION OF INTERCULTURAL EDUCATION OF STUDENTS BY MUSIC ACTIVITIES
}

\author{
Wei Zheyuan \\ ORCID iD 0000-0001-6075-2050 \\ Postgraduate student \\ National Pedagogical Dragomanov University \\ 9 Pirogova Str., 01601 Kyiv, Ukraine \\ 66188584@qq.com
}

\section{ABSTRACT}

The article presents the results of experimental work on introducing the technology of intercultural education of students by music in non-auditing work of a higher educational institution and assessing its effectiveness. It was shown that at the end of the forming stage of the experiment there was a significant decrease in the low level of formation of intercultural education of students in the experimental group and the growth of the indicator of a high level in comparison with the control.

Key words: intercultural education; intercultural upbringing; technology of intercultural education of students by music.

\section{INTRODUCTION}

The study of the intercultural education of students by means of music in the extra-curriculum work of a higher educational institution provided for the development of technology for such educational work. Based on the works of N. A. Ovcharenko (2014), R. Kh. Vainoli (2008), O. M. Olexiuk (2006), we developed the technology of intercultural education of students by means of music, which included two blocks (theoretical and practical), aimed at the implementation of content, forms and methods of educational work From intercultural education of students. The effectiveness of technology was determined by the formation of intercultural education of students by means of music.

\section{PRESENTATION OF THE WORK}

A molding experiment was carried out to introduce the technology of intercultural education of students by means of music in non-audition work of a higher educational institution and assessment of its effectiveness. The formative experiment was conducted in 2016-2017 on the basis of the National Pedagogical Dragomanov University and was carried out under the following stages: preparatory, basic, productive.

In the preparatory phase of the molding experiment, a sample of groups from the general group was made. The experiment was attended by 148 students of the specialties "Social pedagogy" and "Social work", of which 81 persons form the experimental group (EG), in particular, the students of the groups: $31 \mathrm{SP}-29,34$ 
SW - 29, 35 SW - 23, and 67 - control (CG), currently students of the groups: $21 \mathrm{SP}-29,24 \mathrm{SW}-24,25 \mathrm{SP}-21$. This quantitative correlation of groups is related to the fact that during the experimental survey the sample size did not exceed $30 \%$. During the study, we used a systematic (mechanical) sample, where the selection of respondents in the control group was carried out sequentially, through the same interval (sampling step). The step of the sample we calculated according to the formula:

$$
\frac{\mathrm{N}}{\mathrm{n}}=\mathrm{K} \text {, }
$$

$\mathrm{K}$ - sample;

$\mathrm{N}$ - size of the general summation;

$\mathrm{n}-$ size of the selective summation.

At the preparatory stage of the study we conducted:

1. selection of a sample of the general group of students of the specialties "Social pedagogy" and "Social work" and their distribution to the experimental and control groups;

2. a comparative analysis between the indicators of the level of parenting (by separate components) of the control and experimental groups at the beginning of the experimental study was conducted using Fisher's criterion and the homogeneity criterion $\chi^{2}$;

3. the effectiveness of the technology of intercultural education of students by means of music in non-auditing work of a higher educational institution is determined.

To assess the level of formation of the components of intercultural education, the selection and modification of the relevant methods was carried out.

Reliability and probability of the results were checked using Fisher's criterion, whose empirical significance indicated the existence of differences between the percentages of the two samples and the homogeneity criterion $\chi 2$ (Pearson criterion) for checking and comparing two samples to homogeneity.

The experimental study made it possible to determine that students of control and experimental groups with a high and average level of formation of components of the structure of intercultural education constitute a group of students whose intercultural education is generally formed.

Assessment of the level of formation of the indicators of the motivational component of intercultural education of students at the preparatory stage of the molding experiment showed that:

- the level of formation of the goals of the individual to increase his own intercultural education through the perception of musical art consisted of the control group students at the beginning of the experiment - 45 people $(67,16 \%)$, experimental group - 55 people $(66,68 \%)$;

- the level of domination of interest in the culture of the West and the East consisted of control group students at the beginning of the experiment 46 (68,66\%), experimental group - $55(67,91 \%)$;

- the level of depth of motive to perceive musical art in the countries of the West and the East consisted of control group students at the beginning of the experiment - 45 people $(67,16 \%)$, experimental group - 55 (67,91\%). 
In order to determine the emotional-empathic component of intercultural education of students:

- the degree of understanding of the worldview, the empathy of the inner world of the peoples of the West and the East consisted of the control group students at the beginning of the experiment -47 people $(70,15 \%)$, experimental group - 56 people $(69,14 \%)$;

- the degree of emotional reaction to the music of the countries of the West and the East consisted of the students of the control group at the beginning of the experiment -49 people $(73,14 \%)$, the experimental group - 58 people $(71,6 \%)$;

- the level of ability to detect the emotional-figurative essence of musical works of different countries consisted of control group students at the beginning of the experiment - 48 people (71,64\%), experimental group - 57 (70,37\%).

In order to identify the cognitive-identifying component of intercultural education of students:

- the level of knowledge of students about the culture of the peoples of the West and the East consisted of control group students at the beginning of the experiment - 40 people (59,71\%), the experimental group - 46 (56,79\%);

- the level of knowledge about the musical art of the countries of Western Europe and the Far East consisted of the control group students at the beginning of the experiment - 43 people (64,18\%), experimental group - 49 people $(60,49 \%)$;

- the level of the established ability to understand the ethnic identity of the musical culture of different peoples of the world and the awareness of typological and distinctive features in the musical art of the countries of the West and the East consisted of control group students at the beginning of the experiment -45 people (66,16\%), experimental group - 49 people $(60,49 \%)$.

In order to determine the cultural and communicative component of intercultural education of students:

- the level of ethnoculture of a person consisted of control group students at the beginning of the experiment - 42 (62,68\%), experimental group - 49 (60,49\%);

- the degree of tolerant (tolerant) attitude to the musical culture of the West and the East consisted of control group students at the beginning of the experiment - 39 people (59,7\%), experimental group - 49 (60,5\%);

- the formation of communicative personality in the context of musical culture of the countries of Western Europe and the Far East consisted of control group students at the beginning of the experiment - 38 people (56,71\%), experimental group - 49 (60,5\%).

In order to determine the reflexivity and value component of intercultural education of students:

- the formation of artistic reflectivity consisted of 38 students $(56,71 \%)$ in the control group students at the beginning of the experiment; 44 experimental groups $(57,31 \%)$;

- the formation of a value relation to the musical culture of the West and the East consisted of the control group students at the beginning of the experiment 41 persons $(61,19 \%)$, experimental group - 44 persons $(54,32 \%)$;

- the ability to intercultural self-education by means of musical art consisted of control group students at the beginning of the experiment - $39(58,3 \%)$, experimental group - 45 (55,55\%).

At the next stage, effective, the determination of the levels of the components of the structure of the intercultural education of students by means of music in the 
non-auditing work of the higher educational institution at the end of the molding experiment was carried out.

Evaluation of the level of formation of indicators of the motivational component of intercultural education of students at the effective stage of the molding experiment showed that:

- the level of formation of the goals of the individual to increase his own intercultural education through the perception of musical art consisted of the control group students at the end of the experiment - 46 people $68,66(\%)$, experimental group - 72 persons $(88,89 \%)$;

- the level of domination of interest in the culture of the West and the East consisted of control group students at the end of the experiment - 45 people (67,16\%), experimental group - $71(87,65 \%)$;

- the level of depth of motive to perceive musical art in the countries of the West and the East consisted of the control group students at the end of the experiment - 46 people (68,65\%), experimental group - 70 people $(86,44 \%)$.

In order to determine the emotional-empathic component of intercultural education of students:

- the degree of understanding of the worldview, the empathy of the inner world of the peoples of the West and the East consisted of the control group students at the end of the experiment - 48 people $(71,64 \%)$, experimental group 70 people $(86,42 \%)$;

- the degree of emotional reaction to the music of the countries of the West and the East consisted of the control group students at the end of the experiment 48 people (71,64\%), experimental group - 72 persons $(88,88 \%)$;

- the level of ability to reveal the emotional-figurative essence of musical works of different countries consisted of control group students at the end of the experiment - 48 (71,64\%), experimental group - 72 (88,88\%).

In order to identify the cognitive-identifying component of intercultural education of students:

- the level of knowledge of students about the culture of the peoples of the West and the East consisted of the control group students at the end of the experiment - 44 people $(65,67 \%)$, experimental group - $73(90,12 \%)$;

- the level of knowledge about the musical art of the countries of Western Europe and the Far East consisted of the control group students at the end of the experiment - 43 people (57,1\%), experimental group - 72 people $(88,89 \%)$;

the level of the developed ability to understand the ethnic identity of the musical culture of different peoples of the world and the awareness of typological and distinctive features in the musical art of the countries of the West and the East consisted of the control group students at the end of the experiment -44 people (65,67\%), experimental group - 71 people $(87,65 \%)$.

In order to determine the cultural and communicative component of intercultural education of students:

- the level of ethnoculture of a person consisted of control group students at the end of the experiment - $45(67,16 \%)$, experimental group - 72 persons $(88,89 \%)$;

- the degree of tolerant (tolerant) attitude to the musical culture of the West and the East consisted of the control group students at the end of the experiment 44 people $(65,67 \%)$, experimental group - 70 people $(86,42 \%)$;

- the formation of communicative personality in the context of musical culture of the countries of Western Europe and the Far East consisted of 42 control 
group students at the end of the experiment (62,69\%), experimental group $71(87,65 \%)$.

In order to determine the reflexivity and value component of intercultural education of students:

- the formation of artistic reflectivity consisted of control group students at the end of the experiment - 41 (61,19\%), experimental group - $73(90,13 \%)$;

- the formation of a value relation to the musical culture of the West and the East consisted of the control group students at the end of the experiment 40 people (59,7\%), experimental group - 70 people $(86,42 \%)$;

- the ability to intercultural self-education by means of musical art consisted of the control group students at the end of the experiment - 40 people $(59,7 \%)$, experimental group - 71 people $(87,65 \%)$.

\section{CONCLUSIONS}

At the beginning of the experiment, quantitative indices for the students of the control and experimental groups practically do not differ. At the end of the molding stage of the experiment fix a reduction of almost 20,5\% low coefficient of formation of intercultural education of students in the experimental group and a slight increase compared with the control group average. At the same time, the indicator of a high level of the formation of intercultural education among experimental group students increased by almost $18 \%$ compared with the control one. These are the results of experimental work demonstrate the efficiency of our technology intercultural education of students by means of music and the feasibility of its implementation in extracurricular work of higher education.

\section{REFERENCES}

Vainola, R. Kh. (2008). Tekhnolohizatsiia sotsialno-pedahohichnoi roboty [Technologization of social and pedagogical work]. Kyiv, Ukraine: National Pedagogical Dragomanov University.

Ovcharenko, N. A. (2014). Profesiina pidhotovka maibutnikh uchyteliv muzychnoho mystetstva do vokalno-pedahohichnoi diialnosti: teoriia ta metodolohiia: monohrafiia [Professional training of future teachers of musical art to vocal and pedagogical activities: theory and methodology: monograph]. Kryvyi Rih, Ukraine: Roman Kozlov.

Oleksiuk, O. M. (2006). Muzychna pedahohika: Navchalnyi posibnyk [Musical Pedagogy: Textbook]. Kyiv, Ukraine: KNUKIM. 